\title{
Gestaltande av ämnesinnehåll i högstadiets klassrumsundervisning i musik
}

\author{
Eva Kjellander Hellqvist och Karin L. Eriksson
}

I en ombyggd aula undervisar en lärare en åttondeklass i musik. Temat för stunden är musikens byggstenar och läraren frågar eleverna vad harmoni är. Tre förslag kommer upp: harmoni är när en ton läggs över en annan ton och att det leder till att det bildas stämmor, harmoni är när man mår bra och harmoni är lugn pianomusik. Läraren fortsätter:

L: Det som jag skulle säga är harmoni i detta fallet, då vi pratar om byggstenar som bygger upp musiken, då skulle jag mest gå på detta [visar med handen på den elev som kom med första förslaget] faktiskt. För att du pratade om olika toner, som är liksom på varandra [visar med händerna ovanför varandra hur de olika tonerna är på varandra]. Antingen att man sjunger i stämmor, men det kan ju också vara med instrument. Att man har tonen d [spelar d på klaver ${ }^{1}$, att man har tonen fiss [lägger till ett fiss på klaver], och har tonen a [lägger till ett a på klaver]. [Tar hela d-durackordet igen.] Vad tog jag här nu?
E: Ett ackord.
L: Ett ackord!
(Utdrag ur filmdokumentation E.)

Ovanstående exempel illustrerar hur ämnesinnehållet i högstadiets klassrumsundervisning i musik kan gestaltas i praktiken. Citatet visar hur läraren genom att påpeka att "i detta fallet" betyder harmoni att flera toner kombineras med varandra, etablerar en specifik betydelse av "harmoni": den ämnesspråkliga förståelsen av "harmoni". Dessutom sker detta genom olika former av resurser, mer specifikt det talade språket, gester av olika slag som används metaforiskt och genom spel på instrument.

I föreliggande artikel undersöker vi med utgångspunkt i dokumentationer av lektioner i musik på högstadiet musiklärares användning av semiotiska resurser för att kommunicera musikämnets innehåll. Syftet är att identifiera och beskriva hur ämnesinnehållet i högstadiets klassrumsundervisning gestaltas med hjälp av flera samverkande semiotiska resurser.

En grundläggande utgångspunkt för studien är att vi förutsätter att undervisningen är multimodal till sin karaktär (flera olika sätt att kommunicera används, alltså inte enbart det talade språket) och att flera olika semiotiska resurser (såsom till exempel talat språk, musicerande, mimik och kroppsspråk) samverkar i kommunikationen mellan lärare och elev. Att undervisning är multimodal har bland andra Kristina Danielsson på ett övertygande sätt gett exempel på från flera olika ämnesområden, främst inom naturvetenskapliga ämnen. ${ }^{2}$ Hon konstaterar bland annat att:

1 Med klaver avser vi alla klaviaturinstrument såsom digitalpiano, keyboards, piano med flera. 2 Se exempelvis Danielsson 2013a, Danielsson 2016 och Danielsson \& Selander 2016. 
Hur man i kommunikativa situationer kombinerar olika semiotiska resurser är inte slumpmässiga val, utan valen görs utifrån sådant som vilka resurser som är tillgängliga i situationen och vad som upplevs som användbart i sammanhanget, både utifrån deltagarna i den kommunikativa situationen och utifrån själva innehållet. (Danielsson 2013b: 172 f.)

Det andra vi förutsätter är att det i musikundervisningen, liksom inom andra ämnen, förekommer flera olika typer av "språk", ämnesspråk såväl som skolspråk, fackspråk, musikerspråk, vardagsspråk med flera. Vi har vidare valt att avgränsa studien till ämnesspråket i högstadiets klassrumsundervisning i musik. Vårt sätt att se på ämnesspråk ligger i linje med hur det definieras av Ewa Bergh Nestlog. Mer specifikt omfattar ämnesspråk "både verbalspråk (ord) och andra resurser så som symboler, bilder, ljud och gester” (Bergh Nestlog 2019: 9). Bergh Nestlog påpekar också att ett ämnesspråk är multimodalt och rör "ämnesrelevanta strukturer för språk och andra resurser så som symboler, figurer, bilder, diagram, två- och tredimensionella modeller, gester och kroppsspråk" (Bergh Nestlog 2019: 9). Till dessa kan i musikämnet också tillföras det praktiska musicerandet på instrument och genom sång.

I den följande studien används socialsemiotikens "semiotiska resurser" som ett analytiskt verktyg för att illustrera hur musikundervisningens ämnesinnehåll gestaltas. Med semiotisk resurs avses här de handlingar och artefakter som vi använder oss av för att kommunicera med varandra (van Leeuwen 2005: 3). Inom musikundervisning kan detta vara allt från hur läraren använder verbalspråk (det vill säga talat och skrivet språk), gester och kropp till hur denne använder datorer, instrument och andra föremål för att förmedla ett specifikt innehåll. Eftersom de semiotiska resurserna används av ämnesföreträdare för att förmedla och gestalta ämnesinnehållet, betraktas de här som en del av musikämnets ämnesspråk.

Studien baseras på observationer av sex lärares klassrumsundervisning vid lika många tillfällen. Vi har besökt varje lärares undervisning vid ett tillfälle och dokumenterat det med hjälp av filmkamera. ${ }^{3}$ Utgångspunkten för hur vi placerat filmkameran i klassrummet har varit att på så bra sätt som möjligt dokumentera lärarnas användning av olika semiotiska resurser. Samtidigt har vi tagit hänsyn till lärarnas önskemål om placering av kameran. Vid ett tillfälle valde vi att inte filma, då det på plats uppstod önskemål om detta från några av eleverna. Från detta tillfälle finns observationsanteckningar som dokumenterat ämnesinnehåll och hur det gestaltades. Dessa har använts som komplement till de filmade lektionerna, men har av naturliga skäl inte kunnat vara underlag för närmare analyser.

Viss information om undervisningen har vi samlat in genom en webbaserad enkät till lärarna. Där har efterfrågats uppgifter om den specifika lektionen. Ingår den exempelvis i ett visst tema som läraren arbetar med? Är den en del av förberedelser inför ett prov? Var den upplagd så som läraren brukar lägga upp sin undervisning? Om inte, på vilka sätt har den skiljt sig från hur hen annars gör? Lärarna menade att de dokumenterade lektionerna var representativa för hur de arbetar i stort, med undantag för lärare E som angav att hen fick planera om sin lektion då internetuppkopplingen var avstängd. I viss utsträckning har vi även fått tillgång till delar av det undervisningsmaterial som lärarna använt sig av, exempelvis

3 Samtliga informanter arbetar som musiklärare på högstadiet och har gett sitt samtycke till att vi använder det vi dokumenterat för studien. De är nedan anonymiserade. Sedvanliga etiska riktlinjer för samtycke från eleverna och deras målsmän har följts. 
repertoarhäften och grepptabeller. Detta material används nedan som komplement till observationerna och filmerna.

Fokus ligger alltså på hur läraren använder sig av semiotiska resurser för att uttrycka, gestalta och förmedla musikämnets ämnesinnehåll. Resultaten ger därmed underlag för att exemplifiera ämnesspråket hos dessa lärare, men ger däremot inte möjligheter till vidare generaliseringar. Studien är med andra ord en inventering som kan ligga till grund för kommande mer omfattande undersökningar om ämnesspråk i musikämnet i olika årskurser. Genom att fokusera på lärarnas val av olika semiotiska resurser för att gestalta ämnets innehåll, vill vi också visa på hur ämnesspråk kan gestaltas inom ett undervisningsområde som har det klingande - musiken och musicerandet - i centrum.

\section{Forskningsöversikt}

Eftersom det är sannolikt att de språk som används och hur de gestaltas också påverkas av den lärandepraktik som är i fokus, har vi i den följande forskningsutblicken valt att avgränsa oss till forskning om formella lärandepraktiker. ${ }^{4}$

I tidigare forskning om klassrumsundervisning i musik har studieobjekten bland annat varit pedagogisk och musikalisk interaktion i musikundervisning i grundskola och i kulturskola (se Stålhammar 1995), undervisning i gymnasiet med musicerandet i centrum (se exempelvis Zimmerman Nilsson 2009, Asp 2015) och bedömning av ensemblespel (Zandén 2010). Även sociala samspel och identitetsskapande, särskilt mellan elever (se exempelvis Gullberg 2002, Ericsson \& Lindgren 2010), men också mellan elev och lärare (Ferm 2004) och musikaliskt lärande ur ett sociokulturellt perspektiv (Mars 2016) har studerats. Forskning som direkt berör semiotiska resurser och klassrumsundervisning i musik är däremot svår att finna.

Ett undantag är dock Annika Falthins forskning som presenteras i hennes licentiatuppsats (2011) och i hennes avhandling (2015). Båda undersöker meningsskapande i samband med musik i olika undervisningskontexter i högstadiet utifrån ett socialsemiotiskt perspektiv. Fokus är på det innehållsliga och på hur lärare och elever samspelar genom olika semiotiska resurser. I licentiatuppsatsen är undersökningsobjektet elever i en musikklass, som använder sina kunskaper i och om musik för att redovisa uppgifter i andra skolämnen som svenska, religion och fysik. Resultatet visade att det finns flera lager av meningsbärande dimensioner som musik kan tillföra andra ämnen, samt att elevernas kommunikation synliggörs genom olika multimodala aspekter (Falthin 2011). I avhandlingen undersöks hur meningsskapande och meningserbjudande representeras i musicerande i en klassrumskontext. Bland annat visar Falthin flera möjliga sätt att förmedla och uppfatta lärande på (Falthin 2015). Hennes fokus på musicerande gör emellertid att andra delar av musikundervisningen, såsom exempelvis musikhistoria, inte behandlas.

Niklas Pramling och Cecilia Wallerstedt har vidare studerat betydelsen av semiotiska resurser - hos dem "semiotic tools" - när barn i förskola och på lågstadiet ger uttryck för och reflekterar runt sina upplevelser i samband med musiklyssning (Pramling \& Wallerstedt 2009). Deras studie har främst ett elevperspektiv, men visar på vikten av samverkande semiotiska

4 Jämför Folkestad 2006 och Veblen 2012. 
resurser på en generell nivå även i undervisning i musik på andra stadier än högstadiet. De understryker att:

Even if music education may appear to be about performing (doing/playing) rather than explicitly understanding/explaining, it needs to develop generic kinds of knowledge, such as instruments, genres, traditions and sound qualities, which cannot be communicated (effectively) in a non-verbal form. Verbal language appears to be a kind of meta-language for sense making (explaining, directing awareness, making distinctions, formulate relationships, etc.). Hence, even while music education is characterised by being a non-verbal modality and its qualities (as sound), it also needs, to a large extent, to be a verbal kind of activity. Learning to 'go between' the sounding (non-verbal) and the verbal aspects is one of the major challenges facing the learner in music education. (Pramling \& Wallerstedt 2009: 149 f.)

Delar av den designteoretiska forskningen ${ }^{5}$ som behandlar musikundervisning bör också nämnas, särskilt Anna-Lena Kempe (tidigare Rostvall) och Tore Wests forskning på instrumentalundervisning (se exempelvis Kempe \& West 2010). ${ }^{6}$ De har bland annat genom att använda sig av semiotiska resurser som analys verktyg, visat hur olika former av semiotiska resurser samverkar i instrumentalundervisningen.

\section{Ämnesspråk och semiotiska resurser}

Vi har tagit fasta på Ewa Bergh Nestlogs konstaterande att ett ämnesspråk är "ämnesrelevanta strukturer för språk och andra resurser så som symboler, figurer, bilder, diagram, två- och tredimensionella modeller, gester och kroppsspråk” (Bergh Nestlog 2019: 9). Genom ämnesspråket kan vidare ett ämnes ämnesinnehåll, ämnesröster och för ämnet typiska språkoch textstrukturer komma till uttryck (se vidare Bergh Nestlog 2019, särskilt figur 5). Med vårt syfte att studera hur musikundervisningens ämnesinnehåll gestaltas, blir det därmed viktigt att studera lärarnas yttranden och hur dessa utformas. En slutsats från tidigare forskning är att dessa yttranden i de allra flesta fall (alla?) består av en kombination av olika semiotiska resurser, exempelvis talat språk och gestik.

van Leeuwen menar att det är viktigt att använda begreppet "resurs" och inte som inom den traditionella semiotiken "tecken" då det senare visar på något förutbestämt och inte som något som snarare påverkas av sättet det används på. De meningspotentialer som användandet av semiotiska resurser skapar, behöver nödvändigtvis inte vara kända från början (van Leeuwen 2005: 3 f.). Själva kommunikationen och interaktionen är oftast multimodal och genom att koppla samman multimodalitet med semiotiska resurser ges ett brett spektrum av teckensystem som stödjer förståelsen av hur kommunikation fungerar (se exempelvis Kress \& van Leeuwen 2001).

5 Se Leijon \& Lindstrand 2012 för en jämförelse mellan ett socialsemiotiskt multimodalt respektive ett designteoretiskt perspektiv. Där konstateras bland att det senare "erbjuder hjälp att förstå design för lärande, det vill säga förutsättningar och inramning, samt design i lärande; den väg som studenter och lärare designar på egen hand och tillsammans för att nå förväntande läranderesultat" (Leijon \& Lindstrand 2012: 187).

6 Kempe \& West 2010 bygger på deras avhandling Interaktion och kunskapsutveckling. En studie av frivillig musikundervisning (Rostvall \& West 2001). I Kempe \& West 2010 diskuteras emellertid semiotiska resurser mer explicit. 
I den här studien används alltså semiotiska resurser som ett analytiskt verktyg för att beskriva hur musikundervisningens ämnesinnehåll uttrycks och gestaltas. Vi betraktar dem som "funktionella redskap i människors kommunikation och meningsskapande" (Kempe \& West 2010: 61). En viktig aspekt är att olika semiotiska resurser har olika förutsättningar för att gestalta ett ämnesinnehåll. Hur karaktäristiska egenskaper hos ett durackord gestaltas får här exemplifiera detta. I skrift är det exempelvis relativt enkelt att tydligt peka ut likheter och skillnader mellan dur- och mollackord:

Den väsentliga skillnaden mellan dur och moll ligger i respektive grundtreklangers struktur [...] alltså stor + liten ters i dur, liten + stor ters i moll. (Bengtsson 1975: 362)

Samma skillnad kan också uttryckas i notskrift, i Bild 1 exemplifierat av ett d-moll- respektive d-durackord. Notbildens förmåga att beskriva samma karaktäristiska egenskaper för skillnaden mellan dur- och mollackord, är i relation till citatet ovan mer kondenserat och direkt. Notbilden respektive den skriftliga beskrivningen av dur- och mollackord ger alltså delvis olika typer av information av vad som karaktäriserar ett ackord. Genom att kombinera dessa två olika sätt, fördjupas beskrivningen av vad ackord kännetecknas av. Tillsammans kan olika semiotiska resurser därmed ge en bredare och djupare representation av det som ska förmedlas än vad som är möjligt om enbart en semiotisk resurs brukas.

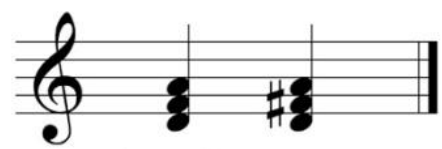

d-moll d-dur

\section{Bild 1. D-moll respektive d-durackord i västerländsk notskrift.}

Valet av semiotisk resurs speglar också den vidare kontext som undervisningen är en del av, mer generellt uttryckt av Danielsson på följande sätt:

A key notion in social semiotics is that semiotic choice both reflects and shapes content. Furthermore, choice of semiotic resource or mode for representation is seen as a result of social, cultural and situational factors in the context in which the communication takes place, including participants and available modes and resources. Hence, from such perspectives, learning something new is intrinsically interwoven with ways of expressing that knowledge through different semiotic choices. (Danielsson 2016: 89) ${ }^{7}$

Lärarnas val av semiotiska resurser i studien bör alltså ses som ett resultat av den vidare kontext som lärarna och eleverna är en del av. Val av semiotiska resurser kan därför antas påverkas av exempelvis klassrumsundervisning som form, musikämnets historik, parallella musikaliska lärandepraktiker, musikindustrins utveckling et cetera. Listan kan göras lång.

Genom vårt fokus på hur innehållet kommer till uttryck, knyter vår analys vidare an till Anna-Lena Kempe och Tore Wests studier av instrumentalundervisning. De påpekar att $\mathrm{i}$ instrumentalundervisning kan innehåll och form inte skiljas åt (Kempe \& West 2010: 82). Deras sätt att se på form ligger mycket nära hur vi ser på ämnesspråk; som val av semiotiska resurser som kommunicerar ett specifikt innehåll. De menar, precis som vi, att

7 Jämför Kress \& van Leeuwen 2001. 
musikundervisning kan "beskrivas som en rik kommunikativ väv av olika semiotiska resurser som musik, tal, noter, gester och ögonkast", och att:

[o]lika semiotiska konfigurationer ger elever och lärare skilda möjligheter att skapa mening i olika situationer. Genom analyser av den semiotiska konfigurationen kan vi få nya kunskaper om kommunikationen, vilket i förlängningen gör det möjligt att designa musikundervisning på ett mer medvetet sätt. (Kempe \& West 2010: 67 f.)

Att studera hur ämnesinnehållet uttrycks i olika samverkande semiotiska resurser, ger därmed också ett bidrag till kunskaperna om de kommunikativa aspekterna av klassrumsundervisning i musik. I ett vidare perspektiv kan studien därför också ses som en pusselbit till en förståelse för de klassiska didaktiska frågorna vad förmedlas och hur förmedlas detta, insatta i musikundervisningens klassrumskontext.

Studien genomförs alltså sammanfattningsvis inom en socialsemiotisk multimodal kontext. Falthin konstaterar att:

Inom socialsemiotisk multimodal analys är forskningsintresset riktat mot individers val av semiotiska resurser, deras teckenskapande i situationer och kontexter som på så sätt kan säga något om individers meningsskapande i specifika sociala och kulturella kontexter. (Falthin 2015: 53)

Genom vårt fokus på lärarnas användning av olika semiotiska resurser för att uttrycka musikämnets ämnesinnehåll, kommer analysen att beskriva just individens (lärarens) val av semiotiska resurser i en specifik kontext (högstadiets klassrumsundervisning i musik).

Vi har inte som avsikt att värdera huruvida de av lärarna i studien använda semiotiska resurserna har eller inte har påverkat elevernas lärande, materialet tillåter inte heller den typen av analyser. Avgränsningen till ämnesspråk innebär vidare att vi inte kommer lyfta andra former av språk som förekommer under de dokumenterade lektionerna, exempelvis vardagsspråk och skolspråk. ${ }^{8}$ Hänsyn har inte heller tagits till lärarnas eventuella intention med att välja en viss semiotisk resurs, utan vi har valt att strikt hålla oss till de semiotiska resurser som kan observeras av en utomstående. Det är också dessa resurser som eleverna får ta del av. I det följande presenteras, analyseras och diskuteras det insamlade materialet. Särskilt fokus läggs på att exemplifiera hur olika semiotiska resurser används för att gestalta ämnets innehåll.

\section{Presentation av de sex musiklektionerna}

I Tabell 1 presenteras generell information om de sex musiklektionerna, såsom uppgifter om det insamlade materialet, årskurs, antal elever, den fysiska klassrumsmiljön, lektionslängd och hur stor del av lektionen som dokumenterats med filmkamera. Som påpekats hade vi inte möjlighet att spela in lektion B. Under lektion C arbetade läraren i flera rum, men det fanns goda möjligheter att dokumentera hens undervisning på klaver. Övriga delar av lektionen dokumenterades med observationsanteckningar.

8 Se vidare Lindberg 2007 för olika aspekter på språk i skolan. 
Tabell 1. Översikt över de sex musiklektionerna.

\begin{tabular}{|c|c|c|c|c|c|}
\hline & $\begin{array}{l}\text { Antal } \\
\text { elever }\end{array}$ & År & Dokumentation & Sal & $\begin{array}{l}\text { Dokumentationens } \\
\text { längd (total } \\
\text { lektionslängd) }\end{array}$ \\
\hline $\mathrm{A}$ & ca 20 & 7 & $\begin{array}{l}\text { Film, anteckningar, } \\
\text { stillbilder. }\end{array}$ & $\begin{array}{l}\text { Musikklassrum med } \\
\text { angränsande mindre } \\
\text { rum. }\end{array}$ & $\begin{array}{l}76 \text { minuter } \\
\text { (70 minuter) }\end{array}$ \\
\hline $\mathrm{B}$ & ca 20 & 9 & $\begin{array}{l}\text { Observations- och } \\
\text { minnesanteckningar, } \\
\text { stillbilder, } \\
\text { undervisningsmaterial. }\end{array}$ & $\begin{array}{l}\text { Aula med angränsande } \\
\text { rum. }\end{array}$ & $\begin{array}{l}60 \text { minuter } \\
(60 \text { minuter })\end{array}$ \\
\hline $\mathrm{C}$ & ca 10 & 8 & $\begin{array}{l}\text { Film, anteckningar, } \\
\text { undervisningsmaterial. }\end{array}$ & $\begin{array}{l}\text { Musikklassrum med } \\
\text { angränsande mindre } \\
\text { rum. }\end{array}$ & $\begin{array}{l}25 \text { minuter } \\
\text { (40 minuter) }\end{array}$ \\
\hline $\mathrm{D}$ & ca 10 & 9 & $\begin{array}{l}\text { Film, anteckningar, } \\
\text { stillbilder, } \\
\text { undervisningsmaterial. }\end{array}$ & Aula. & $\begin{array}{l}57 \text { minuter } \\
\text { (60 minuter) }\end{array}$ \\
\hline $\mathrm{E}$ & ca 20 & 8 & Film, anteckningar. & $\begin{array}{l}\text { Ombyggd aula med } \\
\text { ljudisolerade } \\
\text { övningsrum. }\end{array}$ & $\begin{array}{l}35 \text { minuter } \\
(40 \text { minuter) }\end{array}$ \\
\hline $\mathrm{F}$ & ca 10 & 9 & $\begin{array}{l}\text { Film, anteckningar, } \\
\text { stillbilder, } \\
\text { undervisningsmaterial. }\end{array}$ & $\begin{array}{l}\text { Aula med } \\
\text { gradängsystem. }\end{array}$ & $\begin{array}{l}90 \text { minuter } \\
\text { (90 minuter) }\end{array}$ \\
\hline
\end{tabular}

Som framgår av Tabell 1 är musikundervisningen oftast förlagd antingen till skolans aula, ordinarie eller ombyggd, eller i ett separat musikklassrum. I de allra flesta fall finns mindre, anslutande rum för instrumentspel i grupp eller enskilt. Vid några tillfällen har eleverna också arbetat i anslutande gemensamhetsutrymmen såsom korridorer och matsalar. Några lärare har dock helt saknat tillgång till extra utrymmen av det här slaget. Där genomfördes all undervisning i anslutning till aulans scen.

Klassrummen är oftast möblerade med enbart stolar som kan flyttas runt, kateder och andra möbler kopplade till lärarens behov (exempelvis plats för att ansluta dator till ljud- och bildanläggning), instrument av olika slag (oftast klaver, trumset, gitarrer och elbas). Emellertid har det saknats bord eller motsvarande för eleverna att exempelvis placera anteckningsböcker eller datorer på. De anslutande rummen har haft instrument framtagna.

Under i stort sett alla lektioner som vi observerat, har samtliga utrymmen använts på ett eller annat sätt, vilket bland annat inneburit att lärarna har fått röra sig mycket mellan olika elever och elevgrupper utspridda i flera lokaler. Det innebär att vi inte alltid har haft möjlighet att filma samtliga situationer som läraren var delaktig i. Dessa har istället dokumenterats genom anteckningar under och efter respektive tillfälle.

Det är sannolikt att de olika musikklassrummens utformning och resurser $\mathrm{i}$ form av exempelvis instrument, katedrar och ljudförhållanden, påverkar vilka semiotiska resurser som är möjliga för lärarna att använda sig av och på vilka sätt. Det spelar alltså sannolikt roll för 
undervisningens innehåll och upplägg vilka fysiska möjligheter som lokalerna erbjudit lärarna. ${ }^{9}$ Mer djupgående analyser av hur, har emellertid inte varit möjliga för oss att utforska närmare i den här studien.

\section{Musikundervisningens ämnesinnehåll}

Filmerna har transkriberats med avseende på vad som sker i de olika klassrumssituationer som vi observerat. Dessa transkriptioner har tillsammans med det filmade materialet legat till grund för vår fortsatta analys. Eftersom vi inte på förhand visste vad lärarna skulle behandla på lektionerna blev vårt första analyssteg att identifiera vilka olika typer av ämnesinnehåll som lärarna behandlat. Dessa samlade vi i sex övergripande delområden:

- musikteori: exempelvis genomgång av begrepp som harmoni, takt och tempo

- sång: exempelvis sångövningar, unison sång och röstvård

- instrumentspel, enskilt: exempelvis individuellt spel på klaver

- instrumentspel, ensemble: exempelvis spel tillsammans på flera instrument

- musikhistoria: exempelvis populärmusikhistoria, konstmusikhistoria, genrer och stilar

- musikproduktion med digitala verktyg: exempelvis musikskapande med hjälp av olika programvaror

Samtliga lektioner har haft delområden som varit praktiska (sång, spel på instrument enskilt och i grupp) och teoretiska (musikteori och musikhistoria). Även delområden som behandlar musikproduktion och digitala medier har förekommit vid ett par tillfällen. Se vidare Tabell 2.

Tabell 2. Översikt över vilka delområden som behandlas i de dokumenterade lektionerna.

\begin{tabular}{|l|l|}
\hline & Delområden som har behandlats \\
\hline A & $\begin{array}{l}\text { sång } \\
\text { instrumentspel, enskilt } \\
\text { instrumentspel, ensemble } \\
\text { musikteori }\end{array}$ \\
\hline B & $\begin{array}{l}\text { instrumentspel, ensemble } \\
\text { musikhistoria }\end{array}$ \\
\hline C & $\begin{array}{l}\text { instrumentspel, enskilt } \\
\text { musikproduktion med digitala verktyg }\end{array}$ \\
\hline D & $\begin{array}{l}\text { sång } \\
\text { instrumentspel, ensemble } \\
\text { musikhistoria }\end{array}$ \\
\hline E & $\begin{array}{l}\text { musikteori } \\
\text { musikproduktion med digitala verktyg }\end{array}$ \\
\hline F & $\begin{array}{l}\text { musikteori } \\
\text { musikhistoria }\end{array}$ \\
\hline
\end{tabular}

9 Jämför Öbergs studie av seminarierums utformning inom högre utbildning. Hon konstaterar bland annat att lokalen i sig erbjuder olika möjligheter för de lärare som är verksamma i dem (Öberg 2015). 


\section{Semiotiska resurser: översikt och kategorisering}

Nästa steg i analysen var att identifiera vilka semiotiska resurser som lärarna använde sig av för att förmedla ämnesinnehållet. I tidigare forskning finns delvis olika sätt att kategorisera semiotiska resurser. Det finns emellertid en samsyn om att det kan skifta mellan olika ämnen, undervisningsformer och kontexter vilka resurser som används. Kempe \& West beskriver exempelvis hur de i sina analyser blev uppmärksammade på att "sättet att [i instrumentundervisning, vår anmärkning] kommunicera påverkade händelseförloppet på olika plan" (Kempe \& West 2010: 140). Detta ledde fram till att de i sina analyser kom att betrakta olika skeenden i undervisningen som "olika kommunikativa yttranden i olika resurser" (Kempe \& West 2010: 140, kursivering enligt original). De delar in dessa resurser i språkbruk, musikbruk och gestbruk (Kempe \& West 2010: 140). ${ }^{10}$ Liknande indelningar återfinns $\mathrm{i}$ Danielssons analyser av hur kemilärare undervisar om atomer, mer specifikt: tal, gester, bilder och skrift (Danielsson 2016: 90f.).

Med inspiration från dessa sätt att analysera semiotiska resurser, men med utgångspunkt i de första provanalyserna av vårt insamlade material, har vi valt att kategorisera de semiotiska resurserna på följande sätt:

- språkliga resurser: exempelvis talat och skrivet språk inklusive musikalisk notation

- musikaliska resurser: exempelvis inspelad musik, sång och spel på instrument

- kroppsliga resurser: exempelvis gester, förevisande av fingersättningar och annat bruk av kroppen som meningsbärande medium

- visuella resurser: exempelvis bilder, grepptabeller och rörliga bilder

- digitala resurser: exempelvis digital teknik och programvaror

Vi har i de fall det funnits tveksamheter i vilken kategori en viss semiotisk resurs ska placeras, avgjort från fall till fall utifrån den funktion som resursen haft vid det enskilda tillfället. Handklapp kan exempelvis i en kontext användas som en musikalisk resurs och i en annan kontext vara en del av att förevisa ett musikteoretiskt begrepp och då snarare ses som en kroppslig resurs. Enbart semiotiska resurser som har uttryckt ett ämnesinnehåll har analyserats (jämför Danielsson 2016: 91).

För att visa hur semiotiska resurser används och samverkar för att uttrycka musikämnets innehåll, har vi utgått från vilka delområden som förekommer i lektionerna och valt ett exempel från varje delområde som nedan presenteras närmare. Dessa exempel illustrerar återkommande sätt att använda semiotiska resurser för att gestalta respektive delområdes innehåll.

\section{Delområde: musikteori}

Delområdet musikteori förekommer vid några av lektionstillfällena som avgränsade partier väl skilda från övrig undervisning. I dessa pass är det mycket tydligt att det just är det musikteoretiska ämnesinnehållet som står i fokus i lärarens undervisning. Detta gäller även i de fall då eleverna får sjunga eller utföra andra praktiska moment. Det är också vanligt att lärarna kopplar de musikteoretiska begreppen till klaver eller till spel på gitarr och elbas i samband med sina musikteoretiska genomgångar.

10 Se även Rostvall \& West 2001. 
Lärarna använder sig också av musikteoretisk terminologi som en del av sin vokabulär i andra sammanhang, särskilt i samband med att eleverna spelar på olika instrument. På så sätt införlivas de musikteoretiska begreppen i samtal om musik och musicerande. Framför allt är det grundläggande begrepp och termer såsom puls, takt, tempo, toners namn, hela och halva tonsteg, grundton, ackord, dur, moll, g-klav, korsförtecken och liknande som tas upp.

I följande exempel hämtat från lektion E, utgjorde temat "musikens byggstenar" en relativt stor del av lektionens innehåll. Med detta avser läraren rytm, harmoni och melodi, som alltså är det musikteoretiska ämnesinnehåll som behandlas. Lärarens sätt att arbeta med dessa involverar flera olika semiotiska resurser liksom en kombination av teoretiska och praktiska moment. Det är emellertid det musikteoretiska ämnesinnehållet som hela tiden står i centrum, och under och efter varje mer praktiskt moment återkopplar läraren hela tiden till detta.

Momentet inleds med att läraren säger att de ska ha ett rytmikpass som en introduktion för ensemblespelet som de ska börja med senare under våren och att de ska se närmare på musikens tre byggstenar. Alla eleverna ställer sig upp i stolsraderna och läraren spelar The Doobie Brothers låt "Long train running". Läraren står framför eleverna med ansiktet vänt mot dem. Passet inleds med att läraren på olika sätt markerar pulsen, exempelvis genom att vagga med överkroppen eller gå med markerade steg. Tillsammans konstaterar lärare och elever att det rör sig om en fyrtakt. Därefter fortsätter läraren att mer i detalj gå in på de olika pulsslagens karaktär i en fyrtakt, se Tabell 3.

Tabell 3. Lärare Es genomgång av pulsslag i en fyrtakt. ${ }^{11}$

\begin{tabular}{|c|c|c|c|}
\hline Händelseförlopp & Språklig resurs & Kroppslig resurs & Musikalisk resurs \\
\hline Läraren instruerar. & $\begin{array}{l}\text { "Nu hittar vi bara ettan } \\
\text { här, vi stampar på } \\
\text { ettan." }\end{array}$ & $\begin{array}{l}\text { Pekfingret pekar upp i } \\
\text { luften. }\end{array}$ & \multirow[t]{2}{*}{$\begin{array}{l}\text { Låten "Long train } \\
\text { running" spelas } \\
\text { under hela passet. }\end{array}$} \\
\hline $\begin{array}{l}\text { Läraren räknar } \\
\text { pulsslagen upprepade } \\
\text { gånger, markerar } \\
\text { ettan med rösten. }\end{array}$ & "Ett ${ }^{12}$, två, tre, fyra." & $\begin{array}{l}\text { Markerar med kropp och } \\
\text { mycket tydlig gestik var } \\
\text { ettan kommer. } \\
\text { Övergår till att ta stora } \\
\text { kliv på ettan. }\end{array}$ & \\
\hline
\end{tabular}

Samma mönster upprepas för andra, tredje och fjärde pulsslaget. Det vill säga att låten fortsätter att spelas (musikalisk resurs), läraren anger genom att sticka upp rätt antal fingrar i luften (kroppslig resurs) samt räkna högt (språklig resurs). Därefter arbetar hen med att räkna pulsslagen med emfas på det pulsslag som är aktuellt för tillfället (språklig resurs) och markera detta pulsslag genom framför allt att ta stora kliv i rummet (kroppslig resurs).

Läraren utvecklar ovanstående genom att markera första och tredje pulsslaget, säga "nu får vi feeling”, peka i luften med en respektive tre fingrar samt markera ettan och trean genom att vifta omväxlande med höger respektive vänster hand uppifrån och ner. Efter ett tag övergår hen till att med stora kliv gå fram och tillbaka på första och tredje slaget. På ett liknande sätt

11 I tabellen anges inte visuell eller digital resurs. Gränssnittet för den digitala streamingtjänsten visades dock på en projektorduk för att spela upp musikexemplet.

$12 \mathrm{Vi}$ använder i citaten från lektionsdokumentationerna understrykning för att markera att något sägs med emfas. 
arbetar läraren med det hen kallar för "gospeltestet", vilket mer specifikt innebär att samtliga stampar på första och tredje pulsslaget och klappar händerna på tvåan och fyran. Läraren understryker detta ytterligare genom att samtidigt ta stora kliv på ettan och trean.

Därefter övergår läraren till det hen kallar för "analysdelen", och talar om puls. En elev föreslår att puls är något som går jämnt och läraren gör en liknelse med kroppens pulsslag. En tydligt verbaliserad definition av vad puls är ges dock inte. Däremot väljer läraren att, som hen säger: "visualisera oss en puls". Det innebär att läraren mycket tydligt, så att ljudet från pennan hörs, på en fristående whiteboard ritar upp en rad med prickar (se illustration a i Figur 1). Genom lärarens förfarande hörs ett stadigt och jämnt pulserande ljud från pennan (musikalisk resurs) och tillsammans med den visualisering som genom detta framträder på tavlan (visuell resurs), kan det i sig ses som precisering av vad puls är. Läraren övergår till att prata om begreppet takt och inleder genom att beskriva att en takt är när man börjar dela in pulsslagen i olika perioder. Samtidigt visar hen hur pulsslagen delas in i takter genom att gestikulera imaginära taktstreck med händerna i luften (kroppslig resurs).

Läraren går tillbaka till sin rad med prickar på whiteboarden och delar in dem fyra och fyra (se b i Figur 1). Hen betonar samtidigt att det finns flera olika taktarter, exempelvis fyrtakt. Fyrtakten illustreras med att läraren räknar ett, två, tre och fyra och tar ett stort kliv på ettan och trean och klappar på tvåa och fyran. Det vill säga ett av de moment som hen och eleverna tillsammans gjorde en stund tidigare på lektionen.

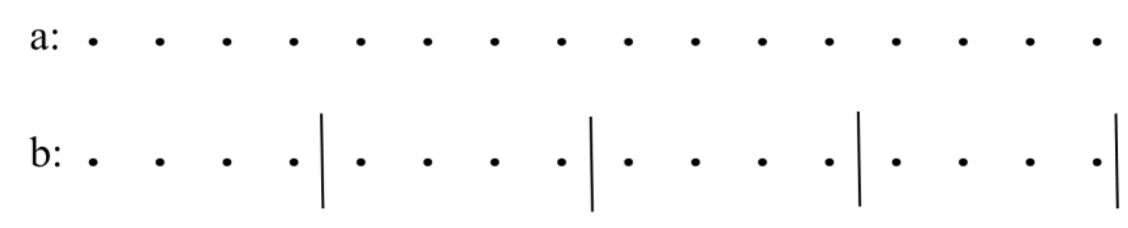

Figur 1. Illustration av hur Lärare E visualiserar puls (a) och takt (b) på whiteboarden.

Sammantaget använder sig alltså läraren av flera olika sätt för att befästa betydelsen av begreppen puls och takt. Som framgår är i detta fall olika kroppsliga resurser tillsammans med det som läraren säger särskilt viktiga i lärarens gestaltning av puls och takt. Hen fortsätter med ett liknande resonemang om harmoni och därefter om melodi. Melodidiskussionen övergår till att de tillsammans sjunger "Broder Jakob", både unisont och i kanon.

För samtliga tre begrepp förtydligas sammanfattningsvis deras ämnesspecifika betydelse genom användandet av musikexempel, spel på klaver och sång. Konstaterande av vad de enskilda begreppen betyder, såsom "harmoni" i artikelns inledande citat, och att melodi till skillnad från harmoni kan förstås som "toner efter varandra" är exempel på detta. Hen knyter vidare konsekvent de tre byggstenarna till vilka instrument som i en populärmusikalisk ensemble har de olika byggstenarna som huvudsaklig uppgift. Exempelvis anges att de flesta instrumenten, men främst trummor, har ansvar för rytmer. För både rytm och melodi får samtliga elever också en egen praktisk erfarenhet. I det första fallet genom det inledande rytmikpasset, i det andra fallet genom att tillsammans sjunga "Broder Jakob". Samtliga tre delar knyts i slutet av lektionen också starkt till det kommande arbetet med ensemblespel genom att tre elever bjuds in att spela trummor (rytm), klaver (harmoni, ackord) och elbas (harmoni, grundton). Övriga elever sjunger (melodi). 
Genom att läraren på olika sätt upprepande gånger understryker vilket ämnesinnehåll de arbetar med (musikteori: rytm, harmoni, melodi) och använder sig av flera olika semiotiska resurser när hen gör detta, gestaltas dessa tre delar på flera olika sätt under lektionens gång. Vi ser också att olika semiotiska resurser används till olika saker. Den digitala resursen används exempelvis enbart för att spela upp det inledande musikexemplet. Däremot är kombinationen av olika språkliga resurser (särskilt muntliga och skriftliga) tillsammans med olika kroppsliga resurser (särskilt gestik och större kroppsrörelser i rummet) och musikaliska resurser (såsom spel på klaver, sång och i slutet ensemblespel) viktiga för att gestalta det specifika musikteoretiska ämnesinnehåll som står i fokus.

\section{Delområde: sång}

Delområde sång har under våra observationer förekommit vid tre olika tillfällen. Vi har här valt att särskilt lyfta hur lärare A arbetar med sång, då hen viker en stor del av lektionen till uppsjungningsövningar, teori om vad som sker när man sjunger och textanalys av sången. Delområde sång framträder därmed i lektion A som ett pass som explicit har sång som lektionens ämnesinnehåll. Detta kan jämföras med lektion D där eleverna sjunger olika visor tillsammans, och där sången mer används som ett medel för att skaffa sig repertoarkännedom, och lektion E, se ovan, där sång fungerar som en hjälp för att förstå musikteoretiska begrepp.

Lärare A arbetar i exemplet med Biebers låt "Love yourself". Inledningsvis är det enbart tjejerna i klassen som är i klassrummet och de sitter i en halvcirkel framför lärarens klaver. Följande konversation utspelar sig:

$\mathrm{L}^{13}$ : Vad är viktigt att tänka på när man ska sjunga?

E: Värma upp rösten.

L: När ni sjunger, vad ska ni tänka på då?

E: Hålla tonen.

L: Vad är det som gör att vi kan sjunga?

E: Stämbanden.

L: Exakt och vad är det som gör att stämbanden låter?

E: Det är luft.

L: När ni skjutsar på med luft, då börjar stämbanden vibrera och det gör att det låter. Andningen är väldigt viktig.

Genom denna muntliga genomgång beskriver läraren vad som sker kroppsligt när de sjunger (språklig resurs). Eleverna ställer sig upp och får lägga en hand på magen för att känna hur luften kommer in eller blåses ut när de på bokstaven s ljuder "s, s, s, s" i stötar (kroppslig och musikalisk resurs). Uppsjungningsövningarna fortsätter enligt Tabell 4.

13 Med L menas läraren och med E avses eleven. 
Tabell 4. Olika semiotiska resurser som används vid en uppsjungningsövning i lektion A.

\begin{tabular}{|l|l|l|l|}
\hline Händelseförlopp & Språklig resurs & Kroppslig resurs & Musikalisk resurs \\
\hline $\begin{array}{l}\text { Läraren använder } \\
\text { klaver och sjunger } \\
\text { före, eleverna sjunger } \\
\text { efter. }\end{array}$ & $\begin{array}{l}\text { Använder handen för } \\
\text { att visa när de ska } \\
\text { börja, samt dirigerar } \\
\text { en fyrtakt. }\end{array}$ & $\begin{array}{l}\text { Tar ton på instrument } \\
\text { samt spelar det som } \\
\text { eleverna ska sjunga. }\end{array}$ \\
\hline $\begin{array}{l}\text { Diskussion om vem } \\
\text { som lyckas/inte lyckas } \\
\text { träffa rätt toner. }\end{array}$ & $\begin{array}{l}\text { ”Nu är du där uppe } \\
\text { [Es namn], en oktav } \\
\text { längre upp". }\end{array}$ & $\begin{array}{l}\text { Illustrerar vad en oktav } \\
\text { längre upp betyder } \\
\text { genom att spela på } \\
\text { klaver. }\end{array}$ \\
\hline $\begin{array}{l}\text { Två grupper turas om } \\
\text { att sjunga } \\
\text { skalövningarna. } \\
\begin{array}{l}\text { Läraren anger vilken } \\
\text { röst de behöver ha. }\end{array}\end{array}$ & $\begin{array}{l}\text { Använder begrepp } \\
\text { som talröst. }\end{array}$ & $\begin{array}{l}\text { Använder huvudet för } \\
\text { att "nicka in" när de } \\
\text { ska börja. }\end{array}$ & Sång. \\
\hline
\end{tabular}

Som framgår i tabellen använder sig läraren av ett flertal samverkande semiotiska resurser även för en kortare sångövning: språkliga genom tal och instruktioner, kroppsliga genom gestik och musikaliska genom att läraren spelar på klaveret.

Lektionen fortsätter därefter med att läraren drar ner en projektorduk och visar texten till Biebers låt (visuell resurs). De sjunger igenom låten en gång och därefter talar de om vad texten handlar om (musikalisk respektive språklig resurs). Det uppstår en kortare diskussion om hur orden ska betonas där läraren och eleverna inte riktigt har samma uppfattning om hur låttexten ska tolkas. Detta skapar en viss dynamik i sången då eleverna betonar på ett annat ställe än läraren. Läraren avslutar med att säga:

När man sjunger ut som [en av tjejerna] blir det bra. Det är när man håller tillbaks och fegar som det blir svårt att träffa tonerna. Man spänner rösten mycket mer. Och om man sitter [visar hur man sjunker ihop] så här, eller om man sitter längre fram på stolen och rakare.

Här används därmed kroppsliga resurser för att understryka vad som är bra respektive mindre bra kroppshållning när man ska sjunga.

Klassens nio killar kommer in och lektionen fortsätter. Också killarna sjunger upp med hjälp av olika övningar som utgår från klaver och olika ljudkombinationer som "bom, bom, bom" och "bam, bam, bam". Den här typen av uppsjungningsövningar är något som eleverna verkar bekanta med. Unisont sjunger de igenom låten en gång. Åter talar läraren om betoningen och vikten av att artikulera väl vid framförandet av en sångtext. Läraren fortsätter med att tala om målbrottet och vad som sker med stämbanden under denna period. Här uttrycks också ämnesinnehållet röstvård som en del av momentet sång. När de slutligen ska sjunga igenom hela låten tillsammans visar läraren dels med huvudnickningar och dels med svepande handrörelser hur de ska dra ut på tonerna (kroppslig resurs), samtidigt som hen kompar på klaver (musikalisk resurs). 


\section{Delområde: instrumentspel, enskilt}

Tillfällen då lärarna instruerar enskilt instrumentspel förekommer enbart i några fall som separata pass. Däremot förekommer det att lärarna exempelvis vid ensemblespel, vid behov går in och ger instruktioner till en enskild elev. För att illustrera olika semiotiska resursers användning inom detta delområde, har vi valt lektion $\mathrm{C}$, där halva klassen sitter och arbetar med spel på klaver i ett särskilt inrett rum. Under lektionen går läraren runt bland eleverna och ger dem individuella anvisningar samt tar del av hur långt eleverna kommit inför kommande betygsättning.

Det ämnesinnehåll som är i centrum är att på klaver ackompanjera olika låtar. Mer specifikt: hitta tonerna på klaveret, spela ett urval av ackord, göra smidiga ackordbyten, samtidigt spela med både höger- och vänsterhand med grundtonen i vänster och övriga ackordtoner i höger och att spela i önskat tempo. I några fall ger läraren också anvisningar för olika sätt att utföra ackorden. Det ämnesinnehåll som läraren kommunicerar med eleverna fokuserar därmed på olika aspekter av att ackompanjera på ett klaver. Främst handlar det om själva spelandet, hur eleverna ska göra för att ackompanjera på ett bra sätt. I samband med detta förmedlar läraren också en uppsättning termer och begrepp för vad eleverna för tillfället gör, bland annat genom att knyta an till en musikteoretisk terminologi.

Detta gör lärare C genom att använda flera olika semiotiska resurser. En del av dem används förevisande, genom att läraren på olika sätt ger exempel på hur en viss handling ska genomföras, ofta genom en kombination av att själv visa på instrumentet (musikalisk resurs) och samtidigt tala om vad hen gör (språklig resurs). En del av de semiotiska resurserna används för att på olika sätt återkoppla till det som en elev gör. Det kan ske genom muntlig återkoppling (språklig resurs) eller rörelser som exempelvis att uppmuntrande nicka under tiden eleven spelar (kroppslig resurs).

I Tabell 5 återges en episod där läraren vill få eleven att spela ackorden i en regelbunden och stadig rytm. Precis före excerpten i tabellen, har eleven spelat ackorden för läraren, som återkopplat med ett "mm" och en kort nick. Det ämnesinnehåll som läraren förmedlar i episoden handlar om att ta ackorden regelbundet så att de följer pulsen. 
Tabell 5. Lärare Cs återkoppling och förevisning av ackordspel i relation till puls.

\begin{tabular}{|c|c|c|c|}
\hline Händelseförlopp & Språklig resurs & Musikalisk resurs & Kroppslig resurs \\
\hline \multirow[t]{2}{*}{$\begin{array}{l}\text { Läraren återkopplar till } \\
\text { vad eleven spelat. }\end{array}$} & $\begin{array}{l}\text { "Mm. Först gjorde } \\
\text { du så." }\end{array}$ & $\begin{array}{l}\text { Spelar ackorden, } \\
\text { treklanger i höger } \\
\text { hand. }\end{array}$ & \\
\hline & $\begin{array}{l}\text { "De är bara för att } \\
\text { visa ackorden." }\end{array}$ & & \\
\hline $\begin{array}{l}\text { Läraren stämmer av med } \\
\text { eleven om hen vet hur } \\
\text { ackorden ska tas. }\end{array}$ & $\begin{array}{l}\text { "Har du koll på hur } \\
\text { många du gör varje } \\
\text { gång?" }\end{array}$ & & \\
\hline \multirow[t]{5}{*}{$\begin{array}{l}\text { Läraren förevisar hur } \\
\text { ackorden ska tas } \\
\text { regelbundet. }\end{array}$} & $\begin{array}{l}\text { "Och det är inte en } \\
\text { långsam låt. Tänk } \\
\text { lite." }\end{array}$ & & \\
\hline & & & $\begin{array}{l}\text { Slår med högra handen } \\
\text { med handflatan riktad } \\
\text { neråt med jämna slag } \mathrm{i} \\
\text { luften }\end{array}$ \\
\hline & $\begin{array}{l}\text { "Nästan, tick, som } \\
\text { sekundvisaren på } \\
\text { klockan." }\end{array}$ & & $\begin{array}{l}\text { Vänder handen } \\
\text { vertikalt och slår med } \\
\text { mycket tydliga slag i } \\
\text { luften. }\end{array}$ \\
\hline & "Boff, boff". & & $\begin{array}{l}\text { Slår med högra handen } \\
\text { med handflatan riktad } \\
\text { neråt med jämna slag i } \\
\text { luften precis ovanför } \\
\text { klaveret. }\end{array}$ \\
\hline & & $\begin{array}{l}\text { Spelar ackorden i } \\
\text { högra hand på det } \\
\text { sätt som de ska } \\
\text { utföras i relation till } \\
\text { pulsen. }\end{array}$ & $\begin{array}{l}\text { Markerar samtidigt } \\
\text { pulsslagen genom att } \\
\text { nicka med huvudet. }\end{array}$ \\
\hline
\end{tabular}

I utdraget som visas i tabellen, använder därmed läraren en kombination av tal (språklig resurs) och handrörelser i luften (kroppslig resurs) för att både återkoppla till eleven vad eleven precis har spelat och strax därefter förevisa för eleven hur hen ska spela ackorden i relation till rytm och tempo. Läraren använder också nickar både för att återkoppla till det eleven har gjort och som förstärkning när hen själv förevisar hur ackorden ska utföras. Delvis samma typer av semiotiska resurser används därmed här för olika syften. Ibland är de en del av lärarens återkoppling till eleven, ibland en del av hens förevisning för hur ackorden ska utföras.

I de individuella situationerna arbetar eleverna ofta också med hjälp av grepptabeller av olika slag. Sådana har i stort sett funnits tillgängliga i samtliga musikklassrum som vi har besökt. Ett exempel på skriftligt material återfinns i Bild 2. Utöver muntligt tal, gestik och förevisande (med kroppen eller på ett instrument), förekommer därmed också ytterligare semiotiska resurser som läraren förser eleverna med och som ofta innehåller både skrift, musiknotation och visualiseringar såsom grepptabeller för bas, gitarr och klaver. 


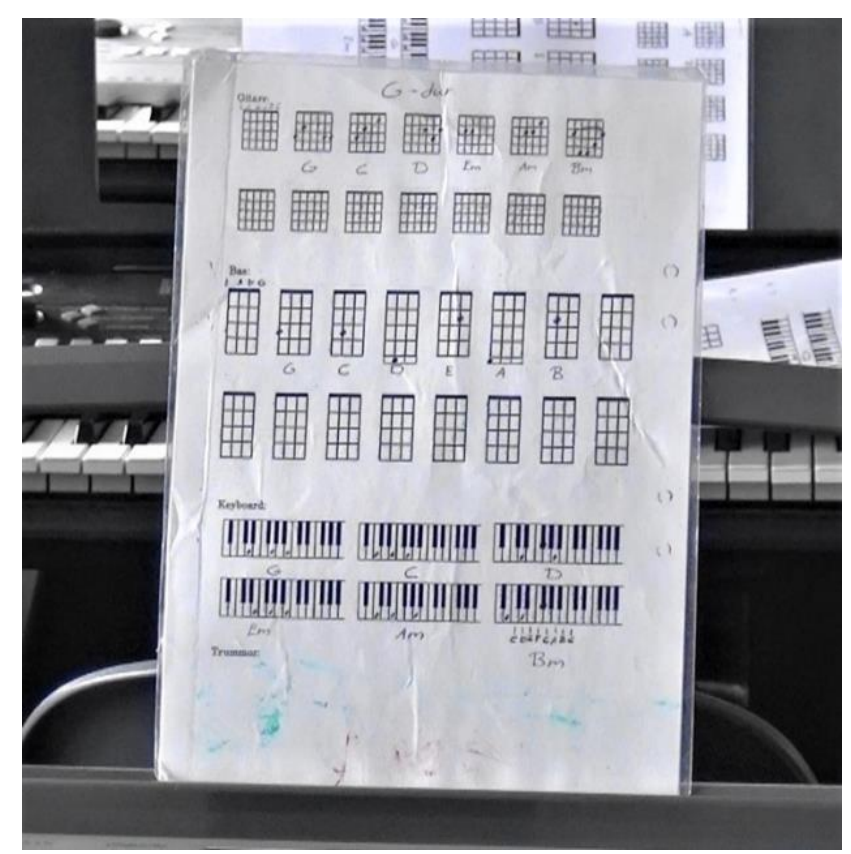

Bild 2. Exempel på tillgängligt material i klassrummet från lektion A. Överst grepptabell för hur olika ackord tas på gitarr, därefter motsvarande för bas och klaver.

\section{Delområde: instrumentspel, ensemble}

Delområdet instrumentspel, ensemble, förekommer vid tre av lektionerna. Som exempel har vi valt lektion $\mathrm{D}$, eftersom den lektionen har ett tydligt avgränsat och relativt långt moment på cirka 30 minuter av lektionens totala 60 minuter. Utöver instrumentspel i grupp, försöker läraren i det här fallet också aktivt att få eleverna att spela och lyssna på varandra liksom att hen för ett resonemang med eleverna om varför det låter som det gör.

Läraren har förberett i aulan för ensemblespel. Elgitarrer, akustiska gitarrer, elbas, trumset, cello och klaverinstrument är placerade vid den lilla scenen längst in i aulan. Dator är inkopplad och visar via projektor musikstyckenas titel och vilka ackord som ska spelas (språklig resurs). Eleverna kommer in, placerar sig på stolar i en halvcirkel och får inledande instruktioner. Läraren ställer sig framför eleverna, tar fram sin fiol och förevisar hur en oktav låter:

L: Lyssna nu, nu kommer jag spela en oktav. En, två samma ton [säger det sista i falsett så att det blir tydligt att den ligger högre]. Hör ni det?

E: Ja! [de nickar]

L: Och om jag tar en millimeter fel. Då låter det falskt. Det är också viktigt att jag kommer att stanna dam-dam-paus-da [visar med hela kroppen hur de ska hålla ut en paus innan sista tonen]. Och en kvart låter så här [spelar].

För att ytterligare förstärka hur viktig pausen är så sjunger hen igen "dam-da-da-dam-dam-här [markerar här överdrivet pausens längd genom att sätta sig ner på en stol och låta hakan vila i handen] da". Kombinationen av de språkliga, musikaliska och kroppsliga resurserna samverkar därmed för att på olika sätt representera centrala aspekter av "paus".

I nästa moment delas eleverna in i tre grupper och får olika instrument tilldelade sig. Stycket de ska spela inledningsvis, Vivaldis "Våren", syns med ackordbeteckningar på projektorduken 
(språklig resurs) och läraren börjar instruera eleven som spelar bas. Läraren sjunger melodin "bom, bom, bom, bom" (musikalisk resurs) - och eleven spelar med (musikalisk resurs). När det är dags att byta ton sjunger läraren - "och a". Hen visar med hela kroppen (kroppslig resurs) när det är ackordbyte och i slutet markeras den paus de övat på tidigare genom att hen likt en dirigent lyfter armarna för att markera att de ska hålla ut näst sista tonen, för att därefter slå av den sista. Efter att de spelat igenom stycket med alla instrument en gång så byter eleverna instrument. De byter också stycke till Beethovens "Ode to joy" och läraren förklarar fyrtakt och tvåtakt genom att säga: "Hur kan man känna när det är fyra slag i takten eller två slag i takten? Två slag i takten heter a la breve-takt" (språklig resurs). Hen sjunger "do-do-do-do" (musikalisk resurs) och säger att detta är fyra slag i takten och sjunger därefter "dodo-dodo" och beskriver detta som a la breve. Hen avslutar med att säga "Vi kör fyra raka" och markerar detta genom att stampa pulsslagen med foten (kroppslig resurs).

Därefter spelar de igenom hela musikstycket långsamt. I Bild 3 illustreras hur läraren genom sin sång och genom talat språk använder sin röst som ledsagare för att visa hur melodin går, för att ge anvisningar till eleverna om vilka ackord som ska tas och till hur slagverket ska spelas (takt 4). Hen varierar sig genom att både tala om (muntligt) vilka ackord som ska spelas precis innan de ska spelas (exempelvis i slutet av takt 2 och 3), och senare sjunga namnet på ackorden samtidigt som de ska tas. Denna korta sekvens visar därmed på hur rösten kan användas på flera olika sätt, både som musikalisk resurs genom att sjunga melodin som eleverna ackompanjerar och sjungande ge anvisningar om vilka ackord som ska spelas, och som en språklig resurs genom talat språk.

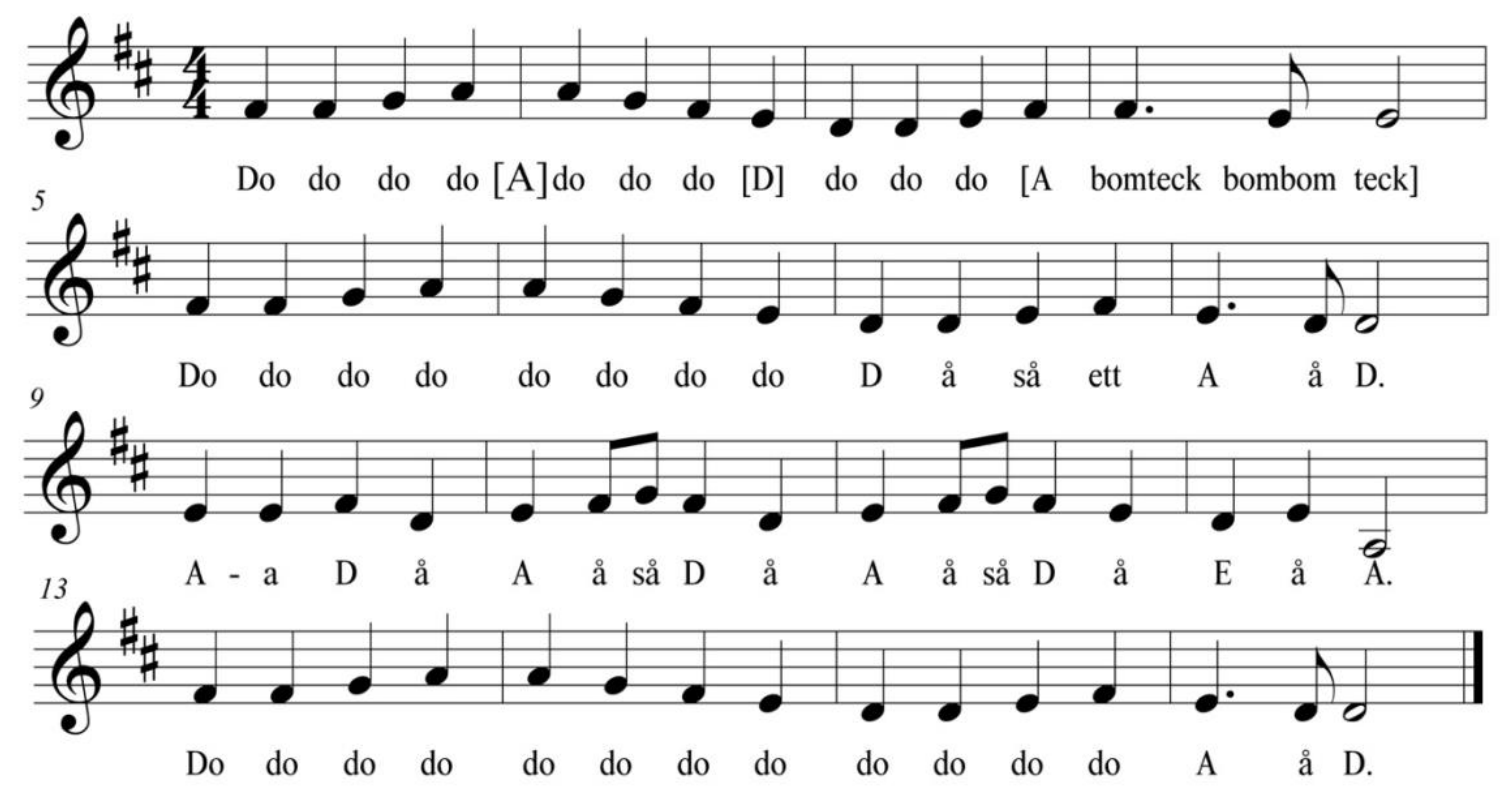

Bild 3. Transkription av lärare Ds sång vid genomspelandet av Beethovens "Ode to joy". Läraren sjunger melodin på stavelser som "do". Ibland inflikar hen anvisningar till eleverna vad de ska spela. Dessa inflikningar är i transkriptionen markerade med hakparentes. De sjungs med andra ord inte. Anvisningarna i takt 4 är till slagverket.

Efter en genomspelning byter de en sista gång instrument så att alla ska ha spelat klaver. Läraren gör likadant som tidigare och sjunger melodin för att ge eleverna en känsla av hur det låter och förstärker genom att säga ackorden. 
Läraren använder alltså muntliga och musikaliska resurser i mycket stor utsträckning, men också kroppsliga och visuella/skriftliga. Hen visar med gestik, huvudnickningar och genom att peka hur hen vill att de ska spela, och eleverna kan också följa ackordsekvenserna på projektorduken. Läraren understryker att syftet inte är att de ska kunna spela styckena felfritt, utan snarare att de ska få en känsla för musiken, lära sig hur de olika ackorden tas på instrumenten samt lära sig lyssna på varandra.

Detta exempel visar hur viktigt det är att eleverna i en och samma situation behöver behärska flera ämnesområden, som musikteori, musikhistoria och instrumentkännedom. För att lärarens instruktioner inte ska bli obegripliga, måste alla till exempel vara överens om hur ett ddurackord tas på de olika instrumenten för att de ska kunna spela tillsammans. Det måste också råda konsensus vad det gäller takt och tempo. Det räcker att en enda elev inte förstått skillnaden mellan fyrtakt och a la breve-takt för att det ska låta osynkroniserat. Den till synes enkla passagen, att spela en ackordsekvens till en enklare melodi, förutsätter därmed flera olika kompetensområden hos eleverna som kan kopplas till undervisningens ämnesinnehåll.

\section{Delområde: musikhistoria}

Musikhistoria har inte haft så stor plats under de lektioner som vi har besökt. Enbart i lektion $\mathrm{D}$ och $\mathrm{F}$ är delområdet representerat och då som kortare moment. I lektion $\mathrm{D}$ är fokus på konstmusikhistoria, i lektion F populärmusikhistoria. Som exempel har vi valt lektion $\mathrm{D}$, eftersom det har ett tydligt avgränsat musikhistoriskt moment under lektionspasset, och för att läraren tydligt anger för eleverna att det är just musikhistoria som de ska arbeta med. Detta exempel illustrerar också hur musikaliska resurser kan användas för att gestalta ett musikhistoriskt ämnesinnehåll.

Under det valda lektionsmomentet om konstmusikhistoria använder sig läraren i huvudsak av dator och projektor för att spela upp stycken och visa bilder. Det som hen spelar upp och de bilder hen visar, knyts genomgående till den specifika musikhistoriska stil som behandlas. Sekvensen föregås av att eleverna haft ensemblespel och sjungit ihop. Läraren avslutar sångdelen och gör en övergång till musikhistoriedelen genom att fråga eleverna om de känner till Bellman:

Sist då är vi inne på Bellman. Vet ni vem det är? Snuskhummern? Han var stand-upkomiker på 1700-talet och alla skrattade. Man förstod det språket då. Ni går i nian och har haft sex och samlevnad. Finns det snusk på teven idag? Snusk finns. Och på 1700talet fanns det ännu mer för man var inte blyg då.

Därefter förs en kort diskussion om vad texten till Bellmans "Glimmande nymf" betyder och hur den kan förstås i dagens samhälle. Läraren sjunger visan och berättar att den ska sjungas med känsla. Detta visar läraren genom att använde både falsettröst och basröst (musikalisk resurs). Läraren använder också kroppsliga resurser i form av mimik när hen sjunger med tydliga ansiktsuttryck för att förmedla känslan i visan. Genom detta får hen också in olika sätt att använda rösten på och att det kallas för falsett- respektive basröst. Momentet inkluderar därmed två olika samverkande ämnesinnehållsområden, musikhistoria och sång (röstanvändning), och flera olika semiotiska resurser (språkliga, kroppsliga och musikaliska). 
Därefter övergår lektionen till att fokusera på det konstmusikhistoriska innehållet. Läraren spelar upp Smetanas "Moldau" (musikalisk resurs) via en streamingtjänst och hen visar med hela kroppen (kroppslig resurs) hur floden flyter fram genom landskapet. Samtidigt visas en bild (visuell resurs) på projektorduken på en mäktig flod. Hen talar om programmusik och att musikstycket är ett exempel på detta. Läraren fortsätter med att tala om impressionism och illustrerar denna inriktning inledningsvis genom att spela en kort melodi på klaveret.

L: Finns det någon melodi? [spelar själv]

E: Nej

L: Lyssna på denna impressionistiska musik [spelar upp via streamingtjänst]. [Hen går runt i rummet och gestikulerar för att förstärka känslan av musiken].

L: Förhoppningsvis har bildläraren pratat om detta också.

E: Det har hen säkert.

Genom att fråga om bildläraren pratat om impressionism knyter hen det musikhistoriska ämnesinnehållet till bildämnets ämnesinnehåll och så även när läraren talar om expressionism och visar ett konstverk, Munchs "Skriet" (språklig respektive visuell resurs). Hen berättar att inriktningen kan ses som en protest mot vacker musik och anger Mozart som exempel på just sådan musik. Därefter leds presentationen vidare till nyklassicismen som beskrivs som en stil där ryska kompositörer strävade efter att hitta tillbaka till just Mozart.

Den nyklassiska stilen illustreras genom spel på klaver. En kort melodi spelas med en ton som avviker från det tonala systemet (musikalisk resurs). Eleverna uppfattar det som felspel, och läraren påpekar att den här typen av avvikelser är just det som kännetecknar stilen (musikalisk resurs för att förmedla ett musikhistoriskt innehåll). Hen förstärker felspelningen genom att visa med hela kroppen att hen gör något som hen inte förväntas göra (kroppslig resurs).

Den sista stil som läraren tar upp kallar hen modern musik och illustrerar den genom Cages stycke "4:33" "14. Läraren visar ett youtubeklipp där stycket framförs och ber eleverna räcka upp handen när de förstår poängen. Hen imiterar sedan själv hur stycket har framförts av en hårdrockare genom att ställa sig i klassisk hårdrockspose med en osynlig gitarr och lätt framåtlutad överkropp (kroppslig resurs). Stycket framkallar en intensiv diskussion hos eleverna huruvida detta kan ses som musik eller inte.

Läraren använder sig därmed av en kombination av semiotiska resurser av olika slag för att gestalta det musikhistoriska ämnesinnehållet. Konstmusikhistoria blir genom detta något som karaktäriseras av enskilda tonsättares kompositionsstil insatt $i$ en vidare kontext med särskilt tydliga kopplingar till konsthistorien. Det är därmed en musikhistorieskrivning som trycker på sammanhängande, kronologiska förlopp som presenteras; impressionismen framställs som en reaktion mot klassicismen, nyklassicismen som en önskan att återkoppla till klassicismen. Konstmusikhistoria som ämnesinnehåll, får därmed en stark betoning på liv (tonsättarna) och verk (deras kompositioner och deras stil).

14 Kompositionen är skriven för alla kombinationer av instrument, med instruktionerna att de inte ska spelas, eftersom det är lyssningsupplevelsen av miljön som är kompositionens syfte (Nationalencyklopedin, hämtad 2019-01-25). 


\section{Delområde: musikproduktion med digitala verktyg}

Delområdet musikproduktion med digitala verktyg återfinns enbart vid två av våra besökta lektioner, lektion C och E. I det ena fallet, lektion C, är eleverna i slutskedet av att med digitala verktyg producera musik och läraren ger främst återkoppling och vägledande anvisningar för hur den låt de arbetar med kan bearbetas ytterligare. I andra fallet, lektion E, är fokus på en specifik funktion i den programvara för musikproduktion som eleverna använder. Som exempel har vi därför valt lärare Es helklassgenomgång av en datorarbetsstation utrustad för musikproduktion, DAW (digital audio workstation) ${ }^{15}$.

Läraren går igenom vad equalizern ${ }^{16}$ (EQ) kan göra och hur eleverna kan arbeta med denna i musiktjänsten. Ämnesinnehållet handlar därmed både om en specifik musikproduktionsterm, dess innebörd och funktion, och om kunskaper om hur en viss programvara för digital musikproduktion fungerar. Lärare $\mathrm{E}$ gör detta genom att själv arbeta i programvaran samtidigt som eleverna följer hens arbete på projektorduken. Som exempel används trummor och läraren beskriver hela tiden vad som sker, se vidare Tabell 6.

Tabell 6. Lärare $E$ visar verktyget automatiserad effekt i den digitala musiktjänsten med EQ som exemplifiering. Musiktjänsten syns på projektorduken under hela passagen, och är inte specificerad $i$ analysen.

\begin{tabular}{|c|c|c|c|c|}
\hline Händelseförlopp & Språklig resurs & $\begin{array}{l}\text { Musikalisk } \\
\text { resurs }\end{array}$ & $\begin{array}{l}\text { Kroppslig } \\
\text { resurs }\end{array}$ & Visuell resurs \\
\hline \multirow[t]{2}{*}{$\begin{array}{l}\text { Läraren } \\
\text { introducerar } \\
\text { "automatiserande } \\
\text { av effekt". }\end{array}$} & $\begin{array}{l}\text { "En } \\
\text { automatiserad } \\
\text { effekt är om } \\
\text { man inte vill ha } \\
\text { på en effekt hela } \\
\text { tiden." }\end{array}$ & & $\begin{array}{l}\text { "hela tiden" } \\
\text { markeras med } \\
\text { en svepande } \\
\text { handrörelse. }\end{array}$ & $\begin{array}{l}\text { På projektorduken } \\
\text { visas programvaran } \\
\text { för musikproduktion. }\end{array}$ \\
\hline & $\begin{array}{l}\text { "Man kan ställa } \\
\text { in så att den } \\
\text { alltså bara gäller } \\
\text { ett tag." }\end{array}$ & & $\begin{array}{l}\text { Vågrörelse i } \\
\text { vänstra handen, } \\
\text { illustrerar } \\
\text { förändring av } \\
\text { effekten över } \\
\text { tid. }\end{array}$ & \\
\hline \multirow[t]{3}{*}{$\begin{array}{l}\text { Exemplifierar med } \\
\text { trumspåret. }\end{array}$} & $\begin{array}{l}\text { "Om vi tar } \\
\text { trummor här då, } \\
\text { till exempel. } \\
\text { Så." }\end{array}$ & & & $\begin{array}{l}\text { Datorpekaren klickar } \\
\text { på en hörlursliknande } \\
\text { ikon. }\end{array}$ \\
\hline & & $\begin{array}{l}\text { Trumspåret } \\
\text { spelas upp. }\end{array}$ & & $\begin{array}{l}\text { Markör rör sig över } \\
\text { trumspåret och } \\
\text { markerar var i spåret } \\
\text { som vi befinner oss. }\end{array}$ \\
\hline & $\begin{array}{l}\text { "Då finns det } \\
\text { den här lilla } \\
\text { svansen." }\end{array}$ & & & $\begin{array}{l}\text { Datorpekaren på } \\
\text { ikon. }\end{array}$ \\
\hline
\end{tabular}

15 Det finns inte en vedertagen svensk vetenskaplig tradition för hur dessa begrepp ska behandlas. Vi följer här Gullö 2010: 13.

16 Verktyg för att jämna ut och balansera ljud. 


\begin{tabular}{|c|c|c|c|}
\hline \multirow{5}{*}{$\begin{array}{l}\text { Läraren visar var de } \\
\text { olika funktionerna } \\
\text { för automatiserade } \\
\text { effekter finns och } \\
\text { beskriver kortfattat } \\
\text { deras innebörd. }\end{array}$} & $\begin{array}{l}\text { "Trycker man } \\
\text { på den står det } \\
\text { automation." }\end{array}$ & \multirow{4}{*}{$\begin{array}{l}\text { Vänder sig } \\
\text { mycket tydligt } \\
\text { mot } \\
\text { projektorduken } \\
\text { och tittar på den. }\end{array}$} & $\begin{array}{l}\text { Markör trycker på } \\
\text { ikon. }\end{array}$ \\
\hline & $\begin{array}{l}\text { "Då kan man } \\
\text { välja vilken typ } \\
\text { av automation } \\
\text { man vill göra." }\end{array}$ & & \\
\hline & $\begin{array}{l}\text { "Vill man göra } \\
\text { en volymkurva." }\end{array}$ & & $\begin{array}{l}\text { Datorpekaren pekar } \\
\text { på "Volume", som } \\
\text { markeras med blå } \\
\text { bottenfärg. }\end{array}$ \\
\hline & $\begin{array}{l}\text { "Panorering. } \\
\text { Det var så här } \\
\text { man valde vilka } \\
\text { högtalare det } \\
\text { skulle vara." }\end{array}$ & & $\begin{array}{l}\text { Datorpekaren pekar } \\
\text { på "Pan", som } \\
\text { markeras med blå } \\
\text { bottenfärg. }\end{array}$ \\
\hline & $\begin{array}{l}\text { "Eller sweep. } \\
\text { Det har med } \\
\text { EQ:n att göra. } \\
\text { Jag kommer } \\
\text { visa hur nu, för } \\
\text { det kan vara lite } \\
\text { svårt att förstå } \\
\text { om man inte } \\
\text { hör. Ni kommer } \\
\text { nog att känna } \\
\text { igen den här } \\
\text { effekten.” }\end{array}$ & $\begin{array}{l}\text { Vänder sig mot } \\
\text { eleverna, ställer } \\
\text { sig bredbent, gör } \\
\text { stora svepande } \\
\text { rörelser med } \\
\text { händerna och } \\
\text { överkroppen i } \\
\text { sidled. }\end{array}$ & $\begin{array}{l}\text { Datorpekaren pekar } \\
\text { på "Sweep", som } \\
\text { markeras med blå } \\
\text { bottenfärg. }\end{array}$ \\
\hline
\end{tabular}

Som framgår i Tabell 6, använder sig läraren av ett antal semiotiska resurser för att introducera automatiserade effekter i programvaran. Mest framträdande är den muntliga presentationen (språklig resurs) som både förklarar specifika begrepp och termer och ledsagar det som sker på projektorduken (visuell resurs). Andra språkliga resurser förekommer också i form av enstaka termer som framträder i programvarans gränssnitt. Dessa förklaras av läraren både genom tal och genom kroppsliga resurser, särskilt används metaforisk gestik med händer och i viss utsträckning övriga kroppen.

Som framgår i ovanstående beskrivning av lärare Es presentation, har musikproduktionsområdet delvis en egen uppsättning med termer och begrepp. Hit hör begrepp som handlar om musikaliska egenskaper hos musiken som kan påverkas i den digitala bearbetningen: bas, diskant, eko, klippa och loopar. Men även mer specifika termer som berör mixningsdelen av arbetet: effekter, automatisering av effekter, panorering, sweep och liknande.

Lärare Es presentation visar också på bredden i delområdets ämnesinnehåll, ett ämnesinnehåll som är starkt knutet till en förståelse för och förmåga att kunna hantera specifika programvaror för digital musikproduktion. Lärare Es instruktioner av specifika funktioner i det digitala verktyget är en del av detta. Det finns en bredd av begrepp varav en del är musikteoretiska, andra starkt kopplade till musikproduktion som område. Dessa ges i lektion E en specifik innebörd genom att läraren, ofta metaforiskt, gestaltar dem genom en 
kombination av olika semiotiska resurser, exempelvis genom att använda kroppen som en kroppslig resurs för att definiera panorering.

\section{En kort exkurs om ämnesröster i delområdet musikproduktion med digitala verktyg}

Vi har i studien fokus på lärarens gestaltning av musikämnets ämnesinnehåll. Det är därmed lärarens ämnesröst som är i fokus (jämför Bergh Nestlog 2019). Men det bör påpekas att det $\mathrm{i}$ de klassrum som vi har vistats i har funnits fler ämnesröster utöver lärarens. Hit hör bland annat elevernas egna uttalanden och formuleringar av det ämnesinnehåll som behandlats, men även exempelvis grepptabeller och annat undervisningsmaterial som eleverna har haft tillgång till under lektionerna. Vid åtminstone en av lektionerna, lektion B, var också läroböcker och notantologier tillgängliga för eleverna.

I delområdet musikproduktion med digitala verktyg, blir frågan om ämnesröster särskilt aktuell. Som framgår i ovanstående exempel från lektion E, bidrar den internetbaserade DAWtjänsten med ett ämnesinnehåll gestaltat genom olika semiotiska resurser såsom skrift, ljud och bild. Detta sker samtidigt som lärarens ämnesröst också påverkar hur delområdet gestaltas. Även den programvara som används bidrar med termer och begrepp. Ofta är dessa engelska, som exemplet med equalizer.

Gunnar Ternhag diskuterar begreppsbildningen i universitetsämnet musikproduktion och menar att det finns tre begreppsspridare i ämnet: "lärarna, handbokslitteraturen och mjukvarorna" (Ternhag 2012: 14). Han påpekar att:

Det är också ett beaktansvärt faktum att musikproduktion som undervisningsämne [på universitetet, vår anm.] förenar flera kunskapsfält, bland annat ljudteknik, elektronik, akustik, musik (med dess många delfält), programmering, m.fl. Ämnets begreppsuppsättning består i realiteten av ett flertal begreppsvärldar eller -system. Delvis sammanfaller de eller har åtminstone inga klara gränser. Begreppssystemen är därtill både skapade och uppbyggda på olika sätt. Några av dem har klara begreppssystem som lärts ut i generationer, till exempel musikteori, medan andra är knutna till praktikdominerade fält, där begreppen har liten skriftlig fixering, till exempel gehörsmusicerande. (Ternhag 2012: 12)

Även om inslagen av musikproduktion med digitala verktyg inom högstadiets klassrumsundervisning som vi dokumenterat inte tar upp den bredd av olika samverkande kunskapsfält som framgår i ovanstående citat, visar observationerna ändå på hur lärarens och mjukvarornas begrepp blir en sammanlänkad del av hur delområdets ämnesinnehåll framställs. Som begreppsspridare blir därmed den programvara som används också en ämnesröst i undervisningen som bidrar till den ämnesspecifika förståelsen av ämnets innehåll. Det gör den genom användandet av flera semiotiska resurser: språkliga (exempelvis specifika begrepp som sweep), visuella (exempelvis genom olika i bild visualiserade ljudvågor) och musikaliska (exempelvis genom möjligheter att skapa och spela upp musik).

I ovanstående exempel kan det också konstateras att den internetbaserade DAW-tjänsten bidrar med begrepp som båda lärarna använder sig av och som blir ett fokus som lärare och elever kan interagera med. Vi kan inte i vårt material avgöra huruvida lärarna i dessa exempel använder tjänstens vokabulär även i andra sammanhang. Det är dock tydligt att tjänstens 
terminologi blir något som läraren behöver förhålla sig till, och som båda lärarna också använder sig av när de själva framställer delområdets innehåll ihop med framför allt musikteoretiska termer och begrepp. Tjänstens framställningssätt, både skriftligt, visuellt och ljudande, blir på så sätt ett inslag i undervisningen som samverkar med men också påverkar lärarnas val av terminologi.

\section{Kombination av olika delområden}

Som antytts i flera av de beskrivna delområdena, är det vanligt att olika delområden kompletterar varandra under ett och samma undervisningsmoment och att det i de enskilda lektionerna sällan uppstår tydliga gränser mellan dem. För att nyansera ovanstående delområdesbeskrivningar vill vi här därför ge ett exempel där delområdet musikhistoria kombineras med musikteori. Som exempel har vi valt en sekvens där lärare $\mathrm{F}$ går igenom musikteori inför ett kommande prov. Med utgångspunkt i en populärmusikalisk låt, "Staying alive" med Bee Gees, som sätts in i en musikhistorisk kontext förs en diskussion som både behandlar delområdet musikhistoria (exempelvis diskussion om genre och stilistik) och delområdet musikteori (med särskilt fokus på tempo, takt och taktslag).

Lektionsavsnittet startar med att läraren spelar upp musikvideon till låten och frågar: "Vad är detta?" Eleverna konstaterar att det är disco och läraren följer upp svaret med: "Hur vet vi det?" En elev svarar att det hörs medan en annan svarar att det syns på klädstilen. Läraren svarar att klädstilen är en stor del av genren men att det inte svarar på frågan om vad vi hör. Låten fortsätter och läraren bryter in i och säger "Tempo!", och fortsätter därefter med att be eleverna att beskriva vad de hör:

L: Beskriv vad ni hör.

E1: Snabb takt.

E2: Snabbare än vanligt.

L: Vad är normalt?

E3: Det är ett, två, tre, fyra eller?

Som centralt framstår lärarens försök att genom diskussion med eleverna om vad de hör skapa en förståelse för genren disco (delområde musikhistoria). Men för att diskutera detta behöver hen också befästa och använda den ämnesspecifika betydelsen av musikteoretiska begrepp såsom tempo, takt och puls. Det båda delområdena framstår här därmed som ömsesidigt beroende av varandra. Det musikhistoriska ämnesinnehållet konkretiseras och förtydligas med hjälp av en ämnesspecifik förståelse av det musikteoretiska delområdet. Detta sker samtidigt som den musikhistoriska kontexten ger läraren möjligheter att konkretisera innebörden av musikteoretiska begrepp och termer och genom att använda dem i ett specifikt syfte. De båda delområdena stärker på så sätt förståelsen av varandra.

På liknande sätt kombinerar lärarna ofta olika ämnesinnehåll med varandra. Inget annat delområde har dock en sådan stark och genomgripande närvaro i de lektioner som vi dokumenterat som musikteori. Det gäller även i sammanhang där två eller flera delområden 
kombineras. Vid i stort sett samtliga fall där detta sker, är musikteori ett av dessa områden. Detta sker i huvudsak på två olika sätt:

- Musikteoretiska begrepp används av läraren som en del i att prata om den musik som hörs eller det som spelas, utan att de musikteoretiska begreppens betydelse förklaras.

- Musikteoretiska begrepp ges en specifik innebörd genom att de används och befästs i relation till exempelvis musikhistoriska inslag eller avsnitt med instrumentspel enskilt eller i grupp.

I det första fallet förutsätts en i sammanhanget redan fastställd ämnesspecifik förståelse för musikteoretiska termer och begrepp, det musikteoretiska delområdet får här främst en stödjande funktion. I det andra fallet förtydligas och befästs det musikteoretiska ämnesinnehållet just genom att användas och gestaltas tillsammans med ett annat delområde. Det senare kan exempelvis ske genom att läraren i samband med att hen ger instruktioner för instrumentspel återkopplar till eleven vad denne precis har spelat genom att använda sig av musikteoretiska begrepp och därigenom ge dessa begrepp en specifik innebörd.

Det är uppenbart att ett visst ämnesinnehåll inom ett delområde ofta behöver kompletteras, utvecklas eller kopplas samman med ämnesinnehållet inom andra delområden. Det musikteoretiska delområdets ställning $\mathrm{i}$ ämnet befästs ofta i dessa sammanhang, inte minst genom att det kombineras både med delområdena sång och instrumentspel enskilt eller i grupp, och med delområdena musikhistoria och musikproduktion med digitala verktyg.

\section{Anpassning av ämnesspråk i den aktuella situationen}

Att ämnesspråkets utformning och gestaltning, oavsett vilket ämnesinnehåll som gestaltas, är beroende av den specifika undervisningskontexten, är en återkommande iakttagelse i våra dokumentationer. Vi har exempelvis dokumenterat hur lärarna anpassar sitt tilltal till enskilda elever, vilket påverkar hur ämnesinnehållet presenteras, men även hur ämnesinnehållet gestaltas genom val av olika semiotiska resurser för olika situationer.

För att illustrera detta har vi valt ett exempel från lärare Cs lektion i samband med spel på klaver. Läraren går runt bland eleverna och lyssnar på deras spel och ger sedan återkoppling på detta. En elev övar på ackordbyten:

L: Du behöver inte göra det så snabbt, då. För den här är ju långsam, nu gjorde du i ett rasande tempo. Vad har du testat den nånstans, i versen eller bryggan, eller hela eller bara lite random?

E: I vers.

L: Ska vi testa det i versen då, om du försöker spela den.

E: [Spelar brutna ackord med både höger- och vänsterhand, pausar mellan ackordbytena.]

L: De funkar ju bra. Vet du vad jag vill att du gör? Vi tar ner det lite i tempo. För det som händer nu, är att du får en, även om den är väldigt, väldigt liten, du får en liten paus när du spelar. Du vill gärna [visar med ett ackord]. Så håller du ut den där lite.

$\mathrm{E}: \mathrm{Mm}$. 
L: [Fortsätter att visa två ackord till med tydlig paus vid ackordbytena.] Ja nu gör jag lite, men lite så åt det där hållet, så jag tänker att vi ska ha den här också nästan lite tråkigt, rakt, så att du får den [spelar ackorden i lägre, stadigt tempo utan paus mellan ackordbytena], och direkt kommer i bytet [spelar vidare]. Jag tänker mig att om vi tar ner tempot lite [spelar ackorden ännu långsammare] så kommer det ticka på lite lättare. Ta ner tempot så att du kör den från början.

Här använder därmed läraren sig av både specifika ämnesrelaterade musikteoretiska begrepp vers, refräng, brygga, tempo - och ett mer vardagligt tal - exempelvis: "lite random" och "tickar på lite lättare”. Samtidigt förevisar hen det som sägs på klaveret. Även om läraren här kombinerar ämnesspecifika termer och begrepp med ett mer vardagligt tilltal, är det tydligt att i de centrala delarna i konversationen - var i stycket de befinner sig och att tempo kan förstås utifrån hur fort eller långsamt det går - väljer läraren att övervägande använda sig av ämnesspråket framför vardagsspråket.

För en annan av eleverna, som också övar på att spela ackord, vill läraren att eleven ska ta ackordet med en treklang i högerhand och med ackordets grundton i vänsterhanden:

L: Kan vi testa och se vad som händer när vi testar att lägga till vänster?

E: [ohörbart]

L: Jo, då är det så att du har a-moll först. Då är det alltid den som sitter längst ner [pekar samtidigt tydligt med pekfingret på klaveret]. [...] När du tar den tonen [pekar på samma ton fast en oktav högre] så är det ett hopp längre ner, [den] är det samma här nere [pekar och spelar tonen en oktav lägre]. Ser du att det är samma här?

E: Jaha.

L: Ser du att det är samma där? Det är ett a, det är bara det att det är ett mörkare a där.

I relation till föregående elev använder sig läraren till den här eleven i högre utsträckning av ett vardagligt språk med mycket få inslag av musikteoretisk terminologi, exempelvis "det är ett mörkare a där". Istället utgår hen från klaveret och pekar ut var de olika tonerna ligger.

De båda exemplen ovan antyder att läraren anpassar sitt ämnesspråk till enskilda elever, särskilt rörande $\mathrm{i}$ vilken utsträckning som hen $\mathrm{i}$ sin konversation använder sig av ämnesspecifika termer och begrepp eller av ett mer vardagligt, metaforiskt resonemang. I båda exemplen använder sig visserligen läraren av spel på klaveret som en del av instruktionerna. I det första exemplet framställs emellertid ämnesinnehållet $\mathrm{i}$ högre utsträckning i det talade än $\mathrm{i}$ det spelade, medan det i det andra exemplet i högre utsträckning förts över till lärarens förevisning på klaveret samtidigt som det talade språket enbart sparsamt innehåller musikteoretiska begrepp.

Jämförelsen visar därmed på hur olika semiotiska resurser kan anpassas efter olika situationer vid ett och samma lektionstillfälle. Valet av semiotiska resurser, eller snarare valet av vilken semiotisk resurs som vid ett givet tillfälle är mest framträdande för att gestalta ett ämnesinnehåll, påverkas med andra ord i hög utsträckning av den enskilda situationen som läraren befinner sig i för tillfället. 


\section{Ämnesspråk - några reflektioner}

Det ämnesinnehåll som förekommit i de sex lektioner som dokumenterats, kan alltså delas in i delområden: musikteori, musikhistoria, sång, instrumentspel (enskilt), instrumentspel (ensemble) och musikproduktion med digitala verktyg. Områdena identifierades utifrån det som förekom vid lektionerna, men sammantaget överensstämmer det också med det syfte som kursplanen i musik i Lgr 11 för grundskolan stipulerar:

Undervisningen ska ge eleverna förutsättningar att tillägna sig musik som uttrycksform och kommunikationsmedel. Genom undervisningen ska eleverna ges möjlighet att utveckla kunskap att använda röst, musikinstrument, digitala verktyg samt musikaliska begrepp och symboler i olika musikaliska former och sammanhang. (Skolverket 2016: $149)^{17}$

Detta visar att trots att undersökningen enbart utgått från ett fåtal dokumentationer så täcker undervisningstillfällena vi observerat in stora delar av det som styrdokumenten föreskriver, som berör ett flertal olika typer av moment som ska behandlas i undervisningen. Lärarna behöver alltså behärska många i vissa delar disparata kunskapsområden, vilket återspeglas i vår studie dels genom den ämnesinnehållsmässiga bredd som sammantaget framträder i de sex lektioner som dokumenterats, dels genom bredden på olika typer av semiotiska resurser som lärarna använder sig av i sin undervisning.

Den tidigare forskning som tangerar vår undersökning, har som konstaterades inledningsvis haft ett stort fokus på det praktiska musicerandet. Genom att ta utgångspunkt i vilket ämnesinnehåll som förekommit i de lektioner som undersöks, framträder det dock att delområdet musikteori återfinns som en del av och i samverkan med samtliga övriga delområden, inklusive de praktiska. Även om det musikteoretiska ämnesinnehållet som förekommit har varit på en grundläggande nivå, verkar delområdet alltså ha en stark ställning inom musikämnet som sådant. Möjligen beror detta på att den musikteoretiska terminologin i sig kan fylla flera funktioner. Den kan dels användas som ett verktyg för att förstå och analysera musik, dels som ett led i att instruera för praktiskt musicerande.

Vi har också sett att ett flertal olika typer av semiotiska resurser används för att förmedla musikämnets ämnesinnehåll. De semiotiska resurserna har i studien betraktats som en del av ämnets ämnesröst. Sammanfattningsvis kan här konstateras att de musiklärare som vi studerat använder sig, precis som lärare i andra ämnen, av flera olika semiotiska resurser i samverkan för att gestalta ett specifikt ämnesinnehåll. Detta gör de på ett sådant sätt att en resurs används i större utsträckning, tillsammans med åtminstone en annan semiotisk resurs så att det som gestaltats i den första resursen får en fördjupad och ofta också mer preciserad innebörd. De olika semiotiska resurserna kan, sammanfattningsvis, sägas förstärka varandras ämnesmässiga innehåll. Detta var ett förväntat resultat i studien då liknande resultat framkommit i studier inom andra angränsande områden.

Med tanke på musikämnets starka framtoning som ett estetiskt ämne med musicerandet $\mathrm{i}$ centrum, är det intressant att se vilken betydelse som andra semiotiska resurser än de musikaliska har för att gestalta musikämnets ämnesinnehåll. Här vill vi särskilt peka på den språkliga resursen talat språk, som i våra dokumentationer har haft en mycket framträdande 
roll för att gestalta ämnesinnehållet inom samtliga delområden. Liksom i Pramling \& Wallerstedt studie, är ett resultat även här alltså att musikpedagogik i stor utsträckning är "a verbal kind of activity" (2009: 150) och att det verbala utgör en viktig del i att begripliggöra exempelvis det praktiska musicerandet.

Det är därför viktigt att uppmärksamma språkliga resursers stora betydelse för ämnet, även i de fall då det praktiska musicerandet är i centrum. Lärarnas förmåga att använda sig av en ämnes- och situationsrelevant terminologi framstår därmed som extra viktig i relation till de språkliga resursernas starka närvaro i de studerade lektionspassen. Om denna iakttagelse har bäring på ett större material återstår att utforska, men den pekar oavsett på behovet av att den enskilde musikläraren får möjlighet till att utveckla sin förmåga att ge röst åt musikämnets ämnesinnehåll genom flera olika typer av semiotiska resurser, inte minst språkliga.

Kroppsliga resurser har också framträtt som semiotiska resurser med stor betydelse för att förmedla musikämnets ämnesinnehåll. Detta gäller alltifrån huvudnickningar och mimik till svepande armrörelser och stora kliv. I flera fall har de kroppsliga resurserna haft en mycket viktig - ibland oumbärlig - funktion för att gestalta och genom det precisera ett specifikt ämnesinnehåll, exempelvis för att definiera begrepp som "harmoni" och "panorering" och för att därigenom befästa begreppens ämnesspecifika betydelse. Men kroppsliga resurser används också för att ge en, ibland svårligen verbaliserad, förståelse för musikaliska förlopp som exempelvis var pauser ska placeras in och på vilket sätt ackordbyten ska utföras så att detta synkas med den underliggande pulsen. Även musikaliska resurser används i vissa fall på ett liknande sätt för att gestalta ämnesinnehåll som är svåra att uttrycka enbart genom muntligt tal, såsom klingande musikexempel som en del av musikhistoriska moment.

En aspekt av ämnesspråkets betydelse, särskilt utifrån ett didaktiskt perspektiv, är dess betydelse för lärandet inom ämnet. En slutsats utifrån tidigare studier är att lärare kan använda sig av olika semiotiska resurser som verktyg i sin undervisning för att möjliggöra lärande. Men vi har inte haft möjlighet att utifrån vår empiri bedöma om ett lärande skett eller ej i de lektioner vi har observerat. Detta har inte heller varit avsikten med undersökningen. Däremot finns det sekvenser i de filmade lektionerna som antyder att lärarnas användande av flera samverkande semiotiska resurser bidragit till ett lärande hos eleverna. Inte minst i de fall där vi dokumenterat hur lärarna instruerar eleverna i samband med sång, instrumentspel enskilt och i grupp och där det i filmerna också går att höra om och i så fall hur elevernas musicerande förändras.

Dessa iakttagelser styrker oss i uppfattningen om vikten av att uppnå en större medvetenhet om hur musiklärare uttrycker musikämnets innehåll. Kunskaper om hur semiotiska resurser används och samverkar för att gestalta ämnesinnehållet, menar vi har en given plats i lärarnas metodologiska verktygslåda. Utöver vår förhoppning att den här studien kan användas som utgångspunkt för flera studier med ett bredare material, hoppas vi därmed också att den kan användas som inspiration till musiklärare för att medvetandegöra och utveckla användandet av olika samverkande semiotiska resurser i sin undervisning. 


\section{Käll- och litteraturförteckning}

\section{Källor}

Observationer i sex högstadieklasser varav fem filmats samt enkäter till lärarna. Materialet insamlat under perioden 2018-01-25-2018-03-19.

\section{Litteratur}

Asp, Karl (2015), Mellan klassrum och scen en studie av ensembleundervisning på gymnasieskolans estetiska program. Lund: Lund University, Malmö Academy of Music.

Bengtsson, Ingmar (1975), "Dur och moll”, i Hans Åstrand (red.), Sohlmans musiklexikon. 2 Campra-Fue. Stockholm: Sohlmans förlag AB, s. 361-363.

Bergh Nestlog, Ewa (2019.), "Ämnesspråk - en fråga om innehåll, röster och strukturer i ämnestexter", HumaNetten 42: 9-30.

Danielsson, Kristina (2013a), "Multimodal literacy i klassrummet. Möjligheter och begränsningar", i Dagrun Skjelbred \& Aslaug Veum (red.), Literacy $i$ laeringskontekster. Oslo: Cappelen Damm AS, s. 120-136.

Danielsson, Kristina (2013b), "Multimodalt meningsskapande i klassrummet", i Åsa Wedin \& Christina Hedman (red.), Flerspråkighet, litteracitet och multimodalitet. Lund: Studentlitteratur, s. 169-188.

Danielsson, Kristina (2016), "Modes and meaning in the classroom. The role of different semiotic resources to convey meaning in science classrooms", Linguistics and education : 88-99.

Danielsson, Kristina \& Selander, Staffan (2016), "Reading multimodal texts for learning - a model for cultivating multimodal literacy", Designs for learning (8)1: 25-36.

Ericsson, Claes \& Lindgren, Monica (2010), Musikklassrummet $i$ blickfånget: vardagskultur, identitet, styrning och kunskapsbildning. Halmstad: Sektionen för lärarutbildning, Högskolan i Halmstad.

Falthin, Annika (2011), Musik som nav i skolredovisningar. Stockholm: Kungliga musikhögskolan.

Falthin, Annika (2015), Meningserbjudanden och val: en studie om musicerande $i$ musikundervisning på högstadiet. Stockholm: Kungliga musikhögskolan.

Ferm, Cecilia (2004), Öppenhet och medvetenhet: en fenomenologisk studie av musikdidaktisk interaktion. Luleå: Luleå tekniska universitet.

Folkestad, Göran (2006), "Formal and informal learning situations or practices vs formal and informal ways of learning", British journal of music education 2: 135-145.

Gullberg, Anna-Karin (2002), Skolvägen eller garagevägen studier av musikalisk socialisation. Luleå: Luleå tekniska universitet.

Gullö, Jan-Olof (2010), Musikproduktion med föränderliga verktyg: en pedagogisk utmaning. Stockholm: KMH Förlaget.

Kempe, Anna-Lena \& West, Tore (2010), Design för lärande i musik. Stockholm: Norstedt.

Kress, Gunther R. \& van Leeuwen, Theo (2001), Multimodal discourse: the modes and media of contemporary communication. London: Arnold.

Leijon, Marie \& Lindstrand, Fredrik (2012), "Socialsemiotik och design för lärande. Två multimodala teorier om lärande, representation och teckenskapande", Pedagogisk forskning i Sverige 3-4: 171-192.

Lindberg, Inger (2007), "Bedömning av skolrelaterat ordförråd”, i Mikael Olofsson (red.), Symposium 2006: bedömning, flerspråkighet och lärande. Stockholm: HLS förlag, s. 83-107. 
Mars, Anette (2016), När kulturer spelar med i klassrummet: en sociokulturell studie av ungdomars lärande i musik. Luleå: Luleå tekniska universitet.

Nationalencyklopedin, "John Cage", http://www.ne.se/uppslagsverk/encyklopedi/lång/johncage (hämtad 2019-01-25).

Pramling, Niklas \& Wallerstedt, Cecilia (2009), "Making musical sense: the multimodal arena of clarifying musical listening", Music Education Research 2: 135-151.

Rostvall, Anna-Lena \& West, Tore (2001), Interaktion och kunskapsutveckling: en studie av frivillig musikundervisning. Stockholm: Centrum för musikpedagogisk forskning (MPC), Musikhögskolan.

Skolverket (2016), Läroplan för grundskolan, förskoleklassen och fritidshemmet 2011, rev. 2016, 3:de kompletterade upplagan. Stockholm: Skolverket.

Stålhammar, Börje (1995), Samspel: grundskola-musikskola i samverkan: en studie av den pedagogiska och musikaliska interaktionen $i$ en klassrumssituation. Göteborg: Avdelningen för musikvetenskap vid Musikhögskolan i Göteborg, Göteborgs universitet.

Ternhag, Gunnar (2012), "På tal om musikproduktion. Begreppsbildning i ett nytt utbildningsämne", i Gunnar Ternhag \& Johnny Wingstedt (red.), P̊̊ tal om musikproduktion: elva bidrag till ett nytt kunskapsområde. Göteborg: Bo Ejeby, s. 925.

van Leeuwen, Theo (2005), Introducing social semiotics. London: Routledge.

Veblen, Kari K. (2012), "Adult music learning in formal, nonformal, and informal contexts", i Gary McPherson \& Graham Welch (red.), The Oxford handbook of music education. Volume II. New York: Oxford University Press, s. 243-256.

Zandén, Olle (2010), Samtal om samspel: kvalitetsuppfattningar i musiklärares dialoger om ensemblespel på gymnasiet. Göteborg: Högskolan för scen och musik, Konstnärliga fakulteten, Göteborgs universitet.

Zimmerman Nilsson, Marie-Helene (2009), Musiklärares val av undervisningsinnehåll: en studie om undervisning $i$ ensemble och gehörs-och musiklära inom gymnasieskolan. Göteborg: Högskolan för scen och musik vid Göteborgs universitet.

Öberg, Lisa (2015), "Rum för seminarium”, i Lotta Jons (red.), Seminariet i högre utbildning: erfarenheter och reflektioner. Lund: Studentlitteratur, s. 193-213. 